VAJDA OLGA

olga.vajda@gmail.com

PhD-hallgató (SZTE BTK)

\title{
Isis megújult szentélye
}

\section{Egy kiállítási katalógus ismertetése}

\author{
The renewed shrine of Isis \\ Review of an exhibition catalogue
}
CAPS-
Sosztarits Ottó - Balázs Péter - Csapláros Andrea (szerk.) (2013):
A savariai Isis szentély

Sistrum. Az Iseum Régészeti Műhely és Tárház kiadványa. Serie A. No. 1.

Szombathely, Szombathely Megyei Jogú Város Önkormányzata. 331 p. ISBN 978-615-5067-03-7

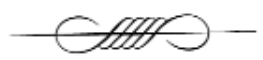

DOI 10.14232/belv.2019.1.14

https://doi.org/10.14232/belv.2019.1.14

Cikkre való hivatkozás / How to cite this article: Vajda Olga (2019): Isis megújult szentélye. Egy kiállitási katalógus ismertetése. Belvedere Meridionale 31. évf. 1. sz. 186-188. pp.

ISSN 1419-0222 (print) ISSN 2064-5929 (online, pdf)

(Creative Commons) Nevezd meg! - Így add tovább! 4.0 (CC BY-SA 4.0)

(Creative Commons) Attribution-ShareAlike 4.0 International (CC BY-SA 4.0)

www.belvedere-meridionale.hu

Az újonnan rekonstruált szentkerület ${ }^{1}$ Iseum Savariense Régészeti Műhely és Tárház néven 2011-ben nyitotta meg kapuit, ebben a modern épületben kapott helyet az Isis savariai otthona címủ állandó kiállítás, ami 2013. március 5-én nyílt meg.

\footnotetext{
${ }^{1}$ A legújabb rekonstrukció Mráv Zsolt és Sosztarits Ottó közreműködésével Mezős Tamás építész tervei alapján készült.
} 
Az állandó kiállításhoz készült vezető egy ugyancsak friss sorozat első köteteként jelent meg 2013-ban. A sorozat igen sokatmondó címet kapott, a Sistrum elnevezés is jelzi, hogy minden a nagy egyiptomi istennő, Isis körül forog majd. ${ }^{2}$

Talán nem túlzás azt állítani, hogy az Iseum Szombathely legismertebb látványossága. Az 1950-es években kerültek elő a szentély faragványai, aminek hatására Szentléleky Tihamér

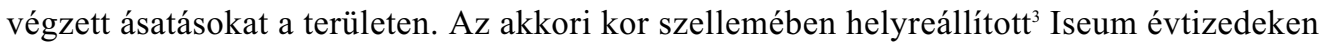
keresztül nagy népszerüségnek örvendett, azonban az épület leromlott állapota és a frissen előkerült adatok miatt is sürgető volt az ismételt rekonstrukció. A 2001-ben megindult újabb kutatások ugyanis lényegesen megváltoztatták a szentélyről alkotott képet.

A megújult, mintegy 900 négyzetméter alapterületű kiállítótérben a Szombathelyen előkerült leletek mellett a provincia római kori vallásosságába, főként az ún. „keleti-kultuszok” világába tekinthetnek be a látogatók. ${ }^{4}$

A kötet az előlap verzón megjelenő címváltozat szerint kiállítási katalógus. Szerencsésebb lett volna a címoldalon is jelölni ezt, nem összezavarni szegény bibliográfiai leírást készítő könyvtárost!

Kiállítások rendezése kapcsán egyre gyakrabban merül fel az a kérdés, hogy a katalógus a szakmának vagy éppen a nagyközönségnek szóljon-e. A jelenlegi kötet véleményem szerint inkább a szakértők számára mutatja be a legújabb kutatási eredményeknek köszönhetően felgyült régészeti tárgyak sokaságát, ugyanakkor talán a laikusok számára

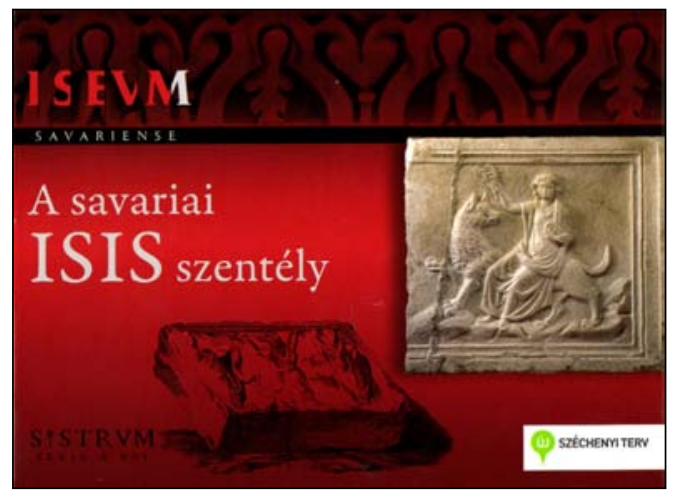
is lebilincselő látványt nyújtanak a tárgyakról készült fotók, valamint a szakmai igényességgel megfogalmazott, mégis általában követhető és érthető rövid tárgyleírások. A régészeti leletek ismertetésénél a szerzők követik a múzeumi tárgykatalógusok leírásának gyakorlatát: származási hely, leltári szám, méretek megjelölésével lényegre törő, pontos leírások.

A katalógus igen nagy mennyiségü, összesen 690 tárgyat felölelő leletanyagot közöl igényesen illusztrált kiállítási katalógus formájában. A könyv egyik érdeme, hogy ezen anyag egy része az utóbbi 20 év ásatásai során került elő, idáig közöletlen volt.

A savariai feltárások során előkerült leletek mellett kölcsönzött tárgyak is szerepelnek a kiállításon és a katalógusban, többek között a Szépművészeti Múzeum Egyiptomi Gyüjteményéből, illetve határon túli múzeumokból, az innsbrucki és a ptuji múzeumból. Ugyanakkor számos másolat is helyet kapott a tárlaton. Ezek olyan, nagy vallástörténeti jelentőséggel bíró, Savarián kívül előkerült tárgyak, melyek bemutatása érthető okokból csak így volt megoldható.

\footnotetext{
${ }^{2}$ A B sorozat kisebb, a múzeumlátogató nagyközönség számára is kezelhetőbb formátumban, mintegy népszerűsítő füzetekként tartalmaz vezetőket az új állandó kiállításhoz: SoszTARITS OTTó (szerk.) (2013): Vezető az Iseum Savariense Régészeti mühely és Tárház állandó kiállitásához. Isis savariai otthona. Sistrum. Az Iseum Régészeti Műhely és Tárház kiadványa. Serie B. No. 1. Szombathely, Szombathely Megyei Jogú Város Önkormányzata. 16 p. ISBN 978-615-5067-05-1; Balázs PÉter - Csapláros Andrea - Sosztarits OtTó (szerk.) (2013): Iseum. Isis temploma Szombathelyen. Sistrum. Az Iseum Régészeti Műhely és Tárház kiadványa. Serie B. No. 2. Szombathely, Szombathely Megyei Jogú Város Önkormányzata. 64 p. ISBN 978-615-5067-04-4.

${ }^{3}$ Szentléleky Tihamér és Hajnóczi Gyula készítette a régészeti-műemléki rekonstrukciót 1963-ban.

${ }^{4}$ A múzeum 2013-ban „Az év múzeuma 2013” díjban részesült.
} 
A katalógus összesen 27 fejezetben, tárgycsoportonként mutatja be a kiállítási anyagot, egy-egy rövid összefoglalással felvezetve azokat. Ezen írások valóban rövidek, többnyire egy oldalra korlátozódnak, így a nagyközönség számára csak tájékoztató, figyelemfelkeltő jelleggel bírnak. Azonban a kötet végén (p. 318-327) található egy részletes irodalom- és rövidítésjegyzék a legfrissebb irodalmi utalásokkal, így aki szeretne az adott témában mélyebben elmerülni, annak e felsorolás átbogarászását ajánlom. A rövidítésjegyzék 327. oldalán rossz fejezetcím szerepel az oldalszám mellett, ami a tördelés során becsúszott hiba lehet.

A különböző témakörök sorrendjének a megválasztásánál talán célszerübb lett volna az összetartozó lelettípusokat egymás után tárgyalni. A könyv a 10. fejezetben érinti a numizmatikai anyagban található vallási témájú ábrázolásokat, majd a 15. fejezetben ismét az Iseum kutatása során elökerült éremanyag a téma. Logikus lett volna ezeket közvetlen egymás után tárgyalni. Ugyanígy összetartozónak érzem a 8. fejezet (Bronzplasztika, fémedények, ékszerek), a 12. fejezet (Fibulák) és a 13. fejezet (Orvoslás és szépségápolás eszközei) témáit.

Külön fejezetet kapott a szentély utóéletéhez kötődő tárgycsoport, és az itt létesült textilmühely és bronzműhely feltárása során előkerült leletanyag ugyancsak külön részben került bemutatásra.

Az Isis-kultusz egyiptomi eredetét tekintve igen helyes választás volt, hogy a kiállítás, és így a katalógus is külön foglalkozik az egyiptomi anyaggal, Isis egyiptomi megjelenésével és az istennőhöz köthető emlékanyaggal (p. 293-317).

Az amúgy egységes szakmai koncepcióval rendelkező kötet egyetlen csorbája a magyar és latin elnevezések nem éppen következetes használata. ${ }^{5}$ Néhány fejezet szöveges részében a latin eredeti fordítása is olvasható, egy-egy kifejezés szakmai néven is szerepel zárójelben, azonban a különböző szerzőknél nem egységes ezek alkalmazása. A nagyközönség számára gyakran még a közismertebbnek tekinthető latin elnevezések is ismeretlenek (mint például a terra sigillata, illetve a fibula), a kevésbé ismert strigilis, lunula, votiv, gladius, phalera vagy éppen a tabula ansata kifejezés pedig teljességgel idegen számukra. Helyenként a közérthetőségre törekszik a katalógus, a 123. oldalon ,gyürükő (gemma)”, a következőn ,gyürükő (intaglio)” megnevezés olvasható - bár a két külön elnevezés egy nem szakmabeli számára némi magyarázatra szorulna. Ugyanakkor egy fejezeten belül is akadnak eltérések, a 143. oldalon az egyik tárgynál „kardszíj (balteus)”, a másik tárgynál csupán „gladius” szerepel, a magyar elnevezés nélkül. Habár véleményem szerint a katalógus inkább a szakmai köröknek készült, mégis hasznos lett volna összehangolni e tekintetben az egyes fejezetek írásait, tárgyleírásait. Én a magam részéről a közérthetőség érdekében a magyar elnevezést követő zárójeles latin megnevezést támogatom.

A kötet végén található egy alaprajzi térkép és konkordancia-jegyzék a kiállításról, melyek segítségével könnyebben eligazodhatunk a kiállítótérben. Ezen a ponton hiányolok egy pár enteriőr képet, ami még színesebbé tette volna az amúgy nagyon színvonalas katalógust. Összességében elmondható, hogy a 2013-ban megjelent, igényesen szerkesztett, nívós kiadványt haszonnal forgathatja minden érdeklődő. Izgalmas a bemutatott anyag, az „egzotikusnak” számító istennő, Isis már az ókori rómaiak fantáziáját is megmozgatta, így a kötet tanulmányozása mellett a kiállítás megtekintése is ajánlatos.

\footnotetext{
${ }^{5}$ A Sistrum B sorozatában láthatóan jobban törekedtek a szerkesztők a közérthetőségre, annak köteteiben következetesen jelennek meg az ókori kifejezések: a magyar elnevezést zárójelben követi a latin elnevezés, illetve a 2. kötetben egy rövid kislexikon is segíti az olvasót az idegen kifejezések világában eligazodni.
} 


\section{MEGJELENT! KAPHATÓ A KIADÓNÁL.}

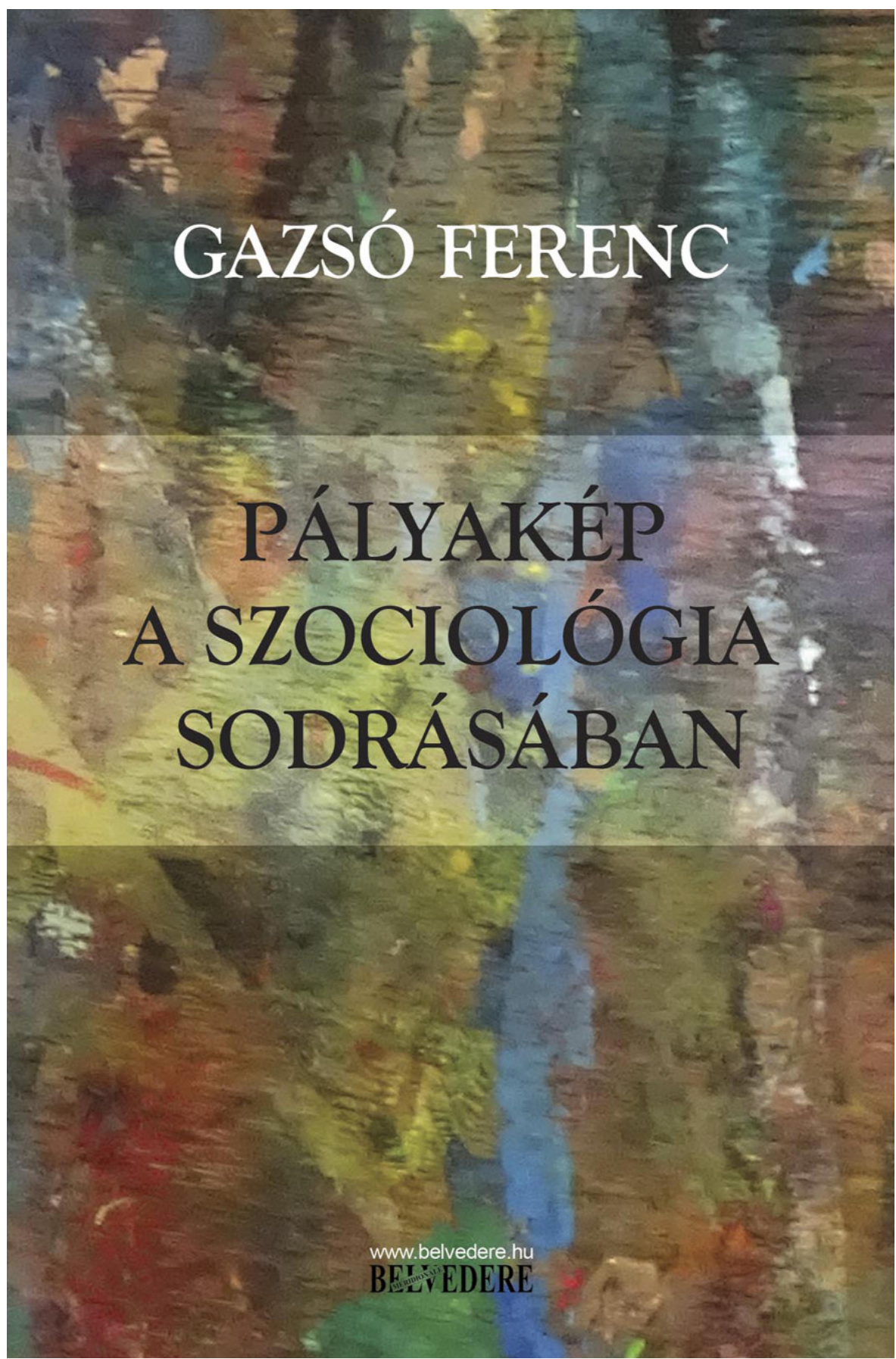




\section{MEGJELENT! \\ KAPHATÓ A KIADÓNÁL.}

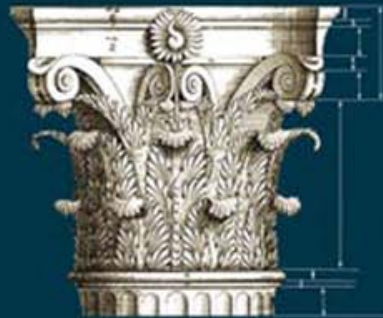

$$
\begin{gathered}
\text { T. HOR VÁTH } \\
\text { ÁNES }
\end{gathered}
$$

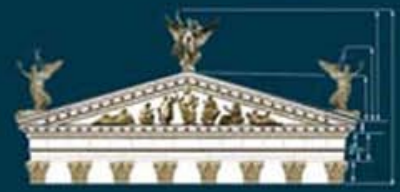

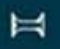

AUGUSTUS
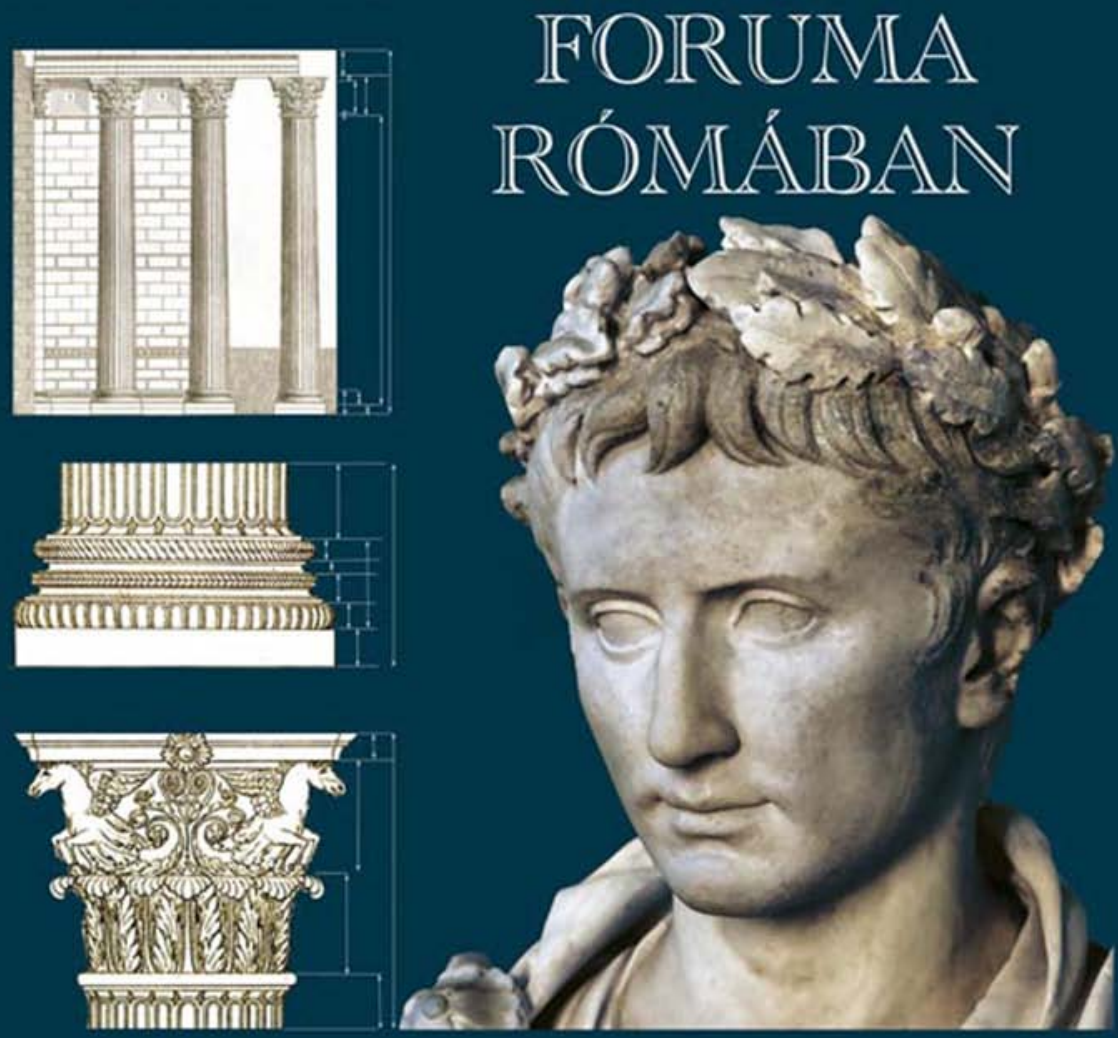